FILOZOFIA

Roč. 74, 2019, č. 10

DOI: https://doi.org/10.31577/filozofia.2019.74.10.2

\title{
MANDEVILLE AND BERKELEY - A MISSING DIALOGUE
}

MAREK TOMEČEK, University of Hradec Králové, Philosophical Faculty, Department of Philosophy and Social Sciences, Hradec Králové, Czech Republic

TOMEČEK, M.: Mandeville and Berkeley - a Missing Dialogue

FILOZOFIA, 74, 2019, No 10, pp. $808-822$

\begin{abstract}
The goal of the present paper is to point out a peculiar style of debate between two well-known philosophers, Bernard Mandeville and George Berkeley, carried out in The Fable of the Bees, Alciphron, and The Letter to Dion. While philosophers often fall short of trying to understand each other in their literary exchanges, they usually try to convince the opponent. This is hardly the case in the Berkeley - Mandeville debate. Here the exchange is not confined to private letters addressing directly the views of the other philosopher. Nor does it aim to address a few experts in the field of moral and political philosophy. Instead, the debate is carried out in public and with the aim of convincing the general reader. This shapes the discussion under consideration here, which is exemplified by the struggle for different evaluation of the normative concept of luxury. For Berkeley, this is a strongly negative word anchored in tradition and ethics, but Mandeville is one of the first thinkers to argue for a positive evaluation of this concept, since it encourages trade and production, and thus prosperity of a nation.
\end{abstract}

Keywords: Berkeley - Mandeville - Luxury - Virtue - Vice - Ethics

\section{Obstacles to Understanding}

Philosophers write books because they disagree with each other. If they agreed, there would be nothing to write about. But the really interesting question sometimes is whether they want to understand each other before they disagree. My treatment of the exchange between Mandeville and Berkeley will hopefully touch on all these questions. Berkeley reacted to the first volume of Mandeville's Fable (1705 - 1728) in the second dialogue of Alciphron (1732) and Mandeville replied in A Letter to Dion (1733), the last publication of his life. Theirs was not the traditional debate where opponents address each other's arguments point by point and try to defeat them. In fact, both thinkers exerted great effort to misrepresent each other's position.

Let us start with Berkeley: he presented Mandeville's thought through the character of Lysicles in such a distorted and unsympathetic manner that Mandeville claimed he had not read his Fable at all. 
Berkeley, however, had very specific reasons for writing as he did. He took himself to be unmasking an opponent who was hiding his real views and intentions and engaging in subterfuge. As early as 1713 Berkeley was meeting London freethinkers in their fashionable coffee-houses and debating them. He realized there is a gap ${ }^{1}$ between what they say in private and what they are prepared to write publicly, so his task is not an easy one: to attempt to draw conclusions from principles that their authors would disavow if challenged, opening himself to the charge of wilful misinterpretation: "a gentleman in private conversation may be supposed to speak plainer than others write, to improve on their hints, and draw conclusions from their principles" (Alc III, 23). ${ }^{2}$ So his target is not The Fable of the Bees as a book, and that is why he does not quote it once in Alciphron, except for the slogan "private vices, public benefits". For the same reason it is problematic to view Lysicles as Mandeville's "spokesman", ${ }^{3}$ and reproach him (and Berkeley) with misstating Mandeville's case.

So if Berkeley is not trying to refute Mandeville's position directly, ${ }^{4}$ but wants to show the consequences that flow from it, how does he go about this task and how far is he successful? First of all, he attempts to provide a translation of Mandeville's de-moralizing 5 talk of vice into plain English, for as Lysicles explains: "Thus in our dialect a vicious man is a man of pleasure, a sharper is one that plays the whole game, a lady is said to have an affair, a gentleman to be a gallant, a rogue in business to be one that knows the world. By this means we have no such things as sots, debauchees, whores or rogues in the beau monde" and Euphranor sums the position up: "Vice then is, it seems, a fine thing with an ugly name" (Alc II, 69). But Berkeley's second, more outspoken spokesman Crito is not very fond of this linguistic innovation, and translates it into plain English: “... to cheat, whore, betray, get drunk...” (Alc II, 84).

\footnotetext{
${ }^{1}$ Berman calls the crypto-atheistic messages in some early modern writers their "esoteric" doctrine, whose purpose was to insinuate denials of God to like minded readers, while not being explicit enough to warrant prosecution. Berman (1988).

${ }^{2}$ When quoting Berkeley, Alc stands for Alciphron, the Roman number is the number of the dialogue in it - Mandeville is dealt with in the second one - and the last number stands for the page in Luce's edition. PC stands for Philosophical Commentaries, the number is the number of the entry. Address to Magistrates has page numbers from the online version. With Mandeville, the number refers to the page in Kaye's edition.

3 "Lysicles and Alciphron are not meant as caricatures of Mandeville and Shaftesbury, but men of fashion who, enamoured of the notions and argumentative style of those writers, have made them part of their conversation" (Walmsley 1990, 125).

${ }^{4}$ The only direct argument could be Euphranor's suggestion that a person who drinks in moderation may be more beneficial to a society and its economy in the long run than a drunkard who, one can expect, will not live very long. So this private vice is not a public benefit. But this argument was in fact first made by Francis Hutcheson and Berkeley merely repeats it.

${ }^{5}$ For a useful summary of the process of stripping the concept of luxury of its moralizing connotations, and Mandeville's role in it, see Berry (1994, 101 - 139).
} 
We may see how such coarse language might give rise to the charge of uncharitable reading of Mandeville in those commentators not attentive enough to Berkeley's rhetorical aim.

The second strategy of resisting the de-moralizing of the language of vice goes deeper and strikes at the heart of the Mandevillian paradox "private vices, public benefits". The semantic tension between the private negativity and public positivity of something which had been understood to be negative both for the individual and the community, namely vice, forms the basis of Mandeville's project and success as a writer. Berkeley rejects the paradox and attempts to reaffirm the traditional dual perniciousness of vice through a series of exempla $^{6}$ reacting to Lysicles' examples. For instance, Berkeley has Lysicles (Alc II, 68) reproduce Mandeville's exemplum of the highway-man (Fable, 88 - 89). Mandeville eschews moral words in his little story to the point of euphemism "A Highway-man having met with considerable Booty...", in which he is matched by the diplomatic Lysicles "when his time is come, a poor family may be relieved by fifty or a hundred pounds set upon his head", tactfully not mentioning the robber's victims and his just execution. Both want to draw our attention away from condemning the criminal and display only the supposed good that comes from his actions. But the forthright Crito does not accept a sanitization of these concepts, he provides many stories where vice does not injure solely the perpetrator, but also the people around him. For instance, "Callicles ... before he became of age ... killed his old covetous father with vexation, and ruined the estate he left behind him, or, in other words, made a present of it to the public, spreading the dunghill collected by his ancestors over the face of the nation" (Alc II, 70). Crito's little stories contrast with Lysicles' callous examples and remind the reader that no man is an island while decrying the purely economic calculations of the public good.

These two aspects of Berkeley's rhetorical strategy, the resistance to the sanitizing jargon of the freethinkers and the stress on the vicious person's injury to other people, have been much misunderstood by commentators ${ }^{7}$ and wilfully misrepresented by Mandeville himself. However, they were successful at least in the sense that they elicited a reply, for Mandeville was not wont to engage in dialogue.

Why did then Mandeville reply at all? We could identify two possible reasons for that. One is that Mandeville felt Alciphron did real damage to his reputation through the quality of its writing: “... Berkeley alone made effective use against him

\footnotetext{
${ }^{6}$ The following analysis draws once again on Walmsley $(1994,129-131)$.

${ }^{7}$ For example, the first line of Miko Tolonen's unpublished article reads "Berkeley seems to have been an angry man." which does not bode well for the objectivity of the following analysis, while exemplifying only the latest in a series of commentators who do not appreciate the subtlety of Berkeley's approach and favour Mandeville. Tolonen, Miko. "Dialogue between Mandeville and Berkeley". Forthcoming. For another example, see (Hundert 1994, 2): "Mandeville exposed in detail Berkeley's wholesale misrepresentation of The Fable."
} 
of his own weapons of satire and ridicule" (Viner 1). The second reason is that Berkeley's critique came from the outside, the two positions did not overlap and could hardly be reconciled, so Mandeville, instead of incorporating it and strengthening his own position through it, as was the case with Butler, could only demarcate it and fortify it against the rival.

However, Mandeville responded in a curious way, for he claims that Berkeley had not read The Fable before he criticised it, that he was reacting to hearsay and to the bad reputation the book already had. Now this rhetorical strategy is symptomatic of Mandeville's broader dismissive attitude to "philosophical debate", and it also allows him to assume the higher moral ground of one who is being condemned without getting a fair hearing. But as a consequence, the whole Letter to Dion is spent repeating what Mandeville had said in his earlier works and denying the unpalatable consequences that Berkeley, according to Mandeville, had drawn from them.

Some commentators value the Letter as the last word of Mandeville, and they seek a development of his position in it. That may be the case, but the Letter's content does not shed any new light on the matter of dispute between both thinkers. And it is positively harmful when taken at face value together with its rhetorical ploy as a proof that Berkeley never read The Fable before criticising it. ${ }^{8}$

So, as we have seen, there is no dialogue between our two thinkers. But why are they talking at all, if they do not want to convince their opponent? Well, as we have said, they want to convince the general public.

The results of our discussion so far have been rather disappointing. Given the nature of the philosophical systems of Berkeley and Mandeville, their confrontation, had they seriously attempted one, would have been complex and probably more interesting. In the following we will attempt to supply what is missing in their actual dialogue.

\section{The Two positions Regarding Virtue and Vice}

Let us proceed now to the two different philosophical positions themselves and let us set them against each other to view the more sharply their differences. "Man is an Animal, formidable both from his Passions, and his Reason; his Passions often urging him to great Evils, and his Reason furnishing Means to achieve them" (Berkeley 1738, 5). This bleak picture of human nature is actually Berkeley's, not Mandeville's. The driving force of human action is the passions, and reason is surprisingly relegated to the subservient role of finding means of gratifying those passions, very much like the role of reason later in Hume, for example. Such an animal is not sociable, and must be tamed to render it fit for society, and that is the job of "civil and religious Institutions". They carry out this task

8 “Berkeley ... seems hardly to have read Mandeville's work" (Hundert 1994, 136). 
through educating the animal and imbibing it with proper notions and principles. What are these notions and how can they influence human conduct? They do it through influencing judgement, which can sometimes overrule the passions, because the notions have a passion-like dimension. An example of a notion is: “...to believe that God scans all his Actions, and will reward or punish them..." (Berkeley 1738, 9). Now, believing in an omniscient God who rewards good acts and punishes evil ones is not a purely theoretical assent to a proposition for Berkeley, for reward and punishment are pleasure and pain, the primary motivators of any animal, man included: "Punishments and Rewards have always had, and always will have the greatest Weight with Men" (Berkeley 1738, 15).

These motivating notions, psychologically present as fear of punishment and desire for reward, are expressed in the language of vice and virtue in the English of Berkeley's time. The state takes care to educate the population in them: “... in a wellordered State, (there is) a certain System of Salutary Notions, a prevailing Set of Opinions ... taught and instilled by the general Reason of the Public; that is, by the Law of the Land" (Berkeley 1738, 8). Now Berkeley takes himself to be a propagator of these notions, it is in fact his job as a clergyman of the established church.

The notions are also culture specific and we shall look for them in vain in other societies. Of three important vices, luxury, avarice and ambition, Berkeley says that they are absent in savages, but not because the savage is himself virtuous and unspoiled by civilisation, "but because the Opportunities and Faculties for such Vices are wanting" (Berkeley 1738, 14). And he gives the example of "savages" who, when given the opportunity, will be drunk for several days and nights together, echoing probably his experience with American natives during his stay in Rhode Island. Moreover, as societal virtues and vices, they are not to be found in the other animals.

The step from pleasure and pain to virtue and vice deserves to be explicated in more detail. ${ }^{9}$ Berkeley is a sophisticated hedonist from the very beginning, from the time of his Philosophical Commentaries (1707 - 1709), these are the basic motivators of action: "No agent can be conceiv'd indifferent as to pain and pleasure" (PC 143), and the content of pleasant and painful ideas is ultimately determined by God, since it is Him who puts the ideas of real things into our minds: "We do not properly speaking in a strict philosophical sense make objects more or less pleasant, but the laws of Nature do that" (PC 144).

If God puts these ideas into our minds, how come we go wrong sometimes and do the wrong thing? How can we misunderstand the divine language so badly? We err because there are two types of pleasures, natural true pleasures with universal validity, and fantastical particular pleasures made up by the mind itself. The latter ones "presuppose some particular whim or taste accidentally prevailing in a sett of people, to which it is

\footnotetext{
${ }^{9}$ In the following analysis I draw on (Olscamp 1970, 47 - 56).
} 
owing that they please" (Olscamp 1970, 49). An example here would be fashionable clothes, houses, and luxury in general. Now pursuit of these fantastical pleasures leads to excess, is irrational and brings only misery, while in the search for the natural pleasures consists true happiness, for they were intended by God to reward us for the right use of our faculties. There is also the traditional scale of pleasures, with sensual delights being the lowest, but everything starts with them: "Sensual Pleasure is the Summum Bonum. This the Great Principle of Morality. This once rightly understood all the Doctrines even the severest of the Gospels may cleerly be Demonstrated" (PC 769). So the right notion of pleasures will help us decipher the difficult precepts of the New Testament and remove the trap of ascetic rigorism that Mandeville will so ably exploit.

Surprisingly, there is no distinction between our pleasure and profit: "I allow not of the Distinction there is made twix't Profit and Pleasure" (PC 541) and the very next entry ties ignoring of this happy coincidence with fundamental mistakes in ethics: "I'd never blame a Man for acting upon Interest. he's a fool that acts on any other Principle. the not understanding these things has been of ill consequence in Morality" (PC 542). So Berkeley sees two pitfalls in the study of ethics: the role of pleasure in the severe strictures of Christianity and the relationship between pleasure and the actor's interest. It is these two flashpoints that Mandeville will attack.

For Berkeley, there is no space to drive in the Mandevillian wedge of dividing private good from the public good. Virtuous conduct is what supports the common good, vicious the opposite. Indeed, the very words "virtue" and "vice" are used to excite men to useful action that will be rewarded and warn them against a dangerous course that will be punished. They are not descriptions of actions, they serve rather as recommendations. Of "virtuous" and "honourable" Berkeley says: "those words should excite in the mind of the hearer an esteem of that particular action and stirr him up to the performance of it..." (Olscamp 1970, 150).

With Mandeville's views on virtue and vice we enter a different universe: "what I call Vices are the Fashionable Ways of Living, the Manners of the Age, that are often practis'd and preach'd against by the same People" (Letter, 48). Two aspects of Mandeville's position on vice stand out here: vice is, in fact, a positive phenomenon, and people who say otherwise are hypocrites. Economically speaking, vice as an excess of consumption creates needs that were not there before, and consequently trades and jobs to satisfy those needs, employing multitudes of people. The increased circulation of money benefits everybody. But it is dirty money, at least according to Mandeville's official position and protestations. For he still wants to claim that vice is evil and virtue good; his definition is very strict, he confines "the Name of Virtue to every Performance, by which Man, contrary to the impulse of Nature, should endeavour the Benefit of others, or the Conquest of his own Passions out of a Rational 
Ambition of being good" (Fable, 48 - 49). Self-denial forms a necessary part of virtue, and whatever is not virtue is vice. This superficially orthodox position of moral rigorism, modelled on the Calvinists and the Jansenists of the sixteenth century, helps Mandeville achieve his rhetorical purposes of presenting his paradox "private vices, public benefits", of in fact eulogizing vices while claiming, tongue-in-cheek, that his book is a book of "exalted morality" (Letter, 41). (Recall Berkeley's warning against divorcing selfinterest, pleasure and profit from good action.)

Mandeville's rhetorical ploy was not lost on his readers, ${ }^{10}$ most enjoyed his writings, some did not, and took him and his book to court, and lost, twice - a testament more to the power of his political protection than to his innocence. Now perhaps we begin to appreciate the difficulty Berkeley was facing of trying to pin down this eel of a writer. Not only does Mandeville evaluate vice and virtue differently to Berkeley, they also play a different and rather fundamental role in his story of the establishing of human society. Man is an animal of conflicting passions for Mandeville as well, who comes into conflict with other men because of desiring the same things and their scarcity. To mitigate the inevitable conflict, "Lawgivers and other wise Men" tried to "to make the People ... believe, that it was more beneficial for every Body to conquer than indulge his Appetites, and much better to mind the Publick than what seem'd his private Interest" (Fable, 42). This extolment of self-denial serves a peace-making function and the social fiction works only because men were led to believe that they were better than animals and should not behave like them. For refraining from their instincts men are rewarded by flattery, "the Aerial Coin of Praise" (Fable, 55) of being called virtuous. So moral virtues are a pro-social fiction, they are "the Political Offspring which Flattery begot upon Pride" (Fable, 51). Berkeley, on the other hand, calls this central principle of Mandeville "a horrible Thing" (Address, 31) - and he is not happy with the reduction of man to a mere animal either.

Mandeville thinks he can explain Berkeley's endeavours: "Thus Sagacious Moralists draw Men like Angels, in hopes that the Pride at least of Some will put 'em upon copying after the beautiful Originals which they are represented to be" (Fable, 52). So Berkeley would be the traditional moralist working within the reigning and socially useful conception of vice and virtue to prevent conflict and strengthen society, a sagacious moralist. And he explicitly envisages Berkeley in this role in the Letter: "Men may differ in Opinion, and both mean well. You, Sir, think it for the Good of Society, that human Nature should be extoll'd as much as possible: I think, the real Meanness and Deformity of it to be more instructive" (Letter, 63 - 64, my italics).

${ }^{10}$ According to Viner, it was "the view of all his contemporaries that Mandeville's rigorism was a sham" (Viner 12). 
This is the first of two points of contact between our two thinkers, the question of their respective roles, so let us explore it in a more detail.

Berkeley, not surprisingly, does not accept this categorisation of his position by Mandeville and, on the contrary, has grave doubts about the integrity of the opposing position: "Euph. Virtue then, in your account, is a trick of statesmen. Lys. It is. Euph. Why then do your sagacious sect betray and divulge that trick or secret of state, which wise men have judged necessary for the good government of the world?" (Alc II, 80) From Berkeley's point of view it is a dangerous statement that virtue is a trick of the politicians, although it claims to be the result of theoretical scientific analysis, for it cannot fail to have political repercussions. If virtue is a trick, why not get rid of it and base society on a true, scientific foundation? That danger is latent in all socially scientific theories, and Berkeley's prescience was borne out by Mandeville's posthumous role in the radical French enlightenment ${ }^{11}$ and its political issue, the French Revolution.

So Mandeville sees Berkeley's account of virtue and vice as the traditional moralist's story that he can scientifically explain away, while Berkeley sees Mandeville's theory as a mere attack on the existing social order in general and the role of Christianity in it in particular. Both are partly right and partly wrong. Mandeville seems to have won in the long run, the Christian concepts of "vice" and "virtue" no longer have the same normative function they had in his time, and so could be deconstructed and subverted by his analysis. But with his rigorist caricature of Christianity he was breaking in an open door, because for Berkeley Christianity and individual profit do not exclude each other. Berkeley, on the other hand, sees no merit in Mandeville's tendency to build a naturalist account of ethics. He reads his story of the origin of society literally, and we cannot really fault him with that. Statements like "the first Rudiments of Morality, broach'd by skilful Politicians, to render Men useful to each other as well as tractable, were chiefly contrived that the Ambitious might reap the more Benefit from, and govern vast Numbers of them with the greater Ease and Security" (Fable, 47, my italics) sound quite provocative and revolutionary. Apparently, this story acquired the meaning of allegory only retroactively in the second volume of the Fable, ${ }^{12}$ published in 1728 as Berkeley was sailing for America.

${ }^{11}$ To which, rather ironically, Alciphron greatly contributed, having been translated as early as 1734 , while the Fable itself only in 1740: "This advance reputation excited interest in the Fable in radical philosophical circles in France, where an established tradition of libertine and social argument was firmly in place" (Hundert 1994, 102).

12 "But it is in Part II, which he wrote largely to correct misconceptions caused by the deliberately paradoxical Part I, that Mandeville most stressed the gradualness of evolution. A great part of the volume is devoted to tracing the growth of society in a surprisingly scientific manner, and completely contradicts the literal interpretation of the allegory in the earlier portion of Part I" (Kaye 1924, 1xv - 1xvi). For a convincing naturalist interpretation of the Fable, see Hundert (1994, 35 - 61). 
Berkeley probably did not read the second volume before writing - 1485215030 Alciphron. This second volume contains Mandeville's considered final position, and so Berkeley could not appreciate its compactness and novelty.

So Mandeville sees himself meta-philosophically to be providing a theory of human social behaviour, while seeing Berkeley attempt to work within that scheme to, perhaps, strengthen the bond of society. But Mandeville's theory is couched in terms that are value-laden and not neutral, and, frankly, borrowed from the moralist's vocabulary, such as "vice" and "virtue", and this fact is both a weakness of the theory as well as a strength of its presentation. Mandevillian paradoxes read well, but he then feels the need to sanitize his use of such emotive words. He does so, for instance, in the parable of dirty streets of London in the Letter $(10-12)$, where he contrasts the subjective yearning of London pedestrians (who "regard Nothing but their own Cloaths and private Conveniency") for cleaner streets with the general explanation that the waste and excrement on the streets is the inescapable result of the "greatness" of the city: "it is impossible London should be more cleanly before it is less flourishing". Private inconvenience once again turns into a public benefit, and Mandeville hopes his pointing out this paradox will stop people wishing for cleaner streets: "if they have any Concern in (London's) Welfare, they will hardly ever wish to see the Streets of it less dirty". The moral seems to be that the scientific analysis leaves everything as it is, it only unmasks some people's confused conceptual thinking and wishes.

With the benefit of three centuries of hindsight we now know that the parable fails, people continue to wish for cleaner streets, that was why they built the London sewage system in the Victorian era, when later they began to choke on smog they switched to cleaner ways of heating their houses, and when they began to choke on car fumes, they introduced the London congestion charge. The parable fails on another, less trivial level, too. There is no catharsis in the explanation and the words, expressing the speakers' wishes, still continue to resonate and be evaluative. It is a constant complaint of Berkeley that Mandeville divorces the words not only from their evaluative function, but from their normative and political function: "Can any thing be more inconsistent than to condemn in practice what is approved in speculation? Truth is one and the same, it being impossible a thing should be practically wrong and speculatively right" (Alc II, 74).

The obstinate words refuse to relinquish their value-laden connotations, and in the Fable's second volume and the Origin of Honour (1732) Mandeville attempts to devise new terms, purely technical ones this time. "Self-love" is common to all animals, but "selfliking" 13 belongs only to man, and it is the morally acceptable expression of pride.

13 "He coined the term in order to answer the need for an emotionally neutral way of describing the workings of the passions... (and ...in response to criticism)" (Hundert 1994, 54). 
According to Jeremy Bentham, Mandeville, by devising such new terms had "broken the chains of ordinary language" (Hundert 1994, 61) and Hundert even speaks of "establishing a science of unsocial yet socialized man on the ruins of an exhausted language of morals" (Hundert 1994, 61). Thus Mandeville can be portrayed as discarding the old vocabulary and groping for a new one, but the question remains whether he in fact finds it. After all, his "self-liking" has not stood the test of time.

For his part, Berkeley is a rather conservative speaker of English, and does not approve of the free-thinkers' conceptual innovations. ${ }^{14}$ From his perspective of reading the Fable's first volume, the sweeping generalizations ${ }^{15}$ and semantic paradoxes of pitting familiar words into unfamiliar positions turn it into a tale of twisting of old words with a smattering of anti-clericalism. Mandeville himself is disarmingly forthright about his preferred bombastic style and intention: "the true reason why I made use of the title Private Vices, Publick Benefits ... was to raise Attention: As it is generally counted to be a Paradox, I pitch'd upon it in Hopes that those who might hear or see it, would have the Curiosity to know, what could be said to maintain it; and perhaps sooner buy the Book, than they would have done otherwise" (Letter, 54). A stronger contrast in styles we could hardly devise: when Berkeley wrote a book refuting the material substance, quite a paradoxical topic, he purposefully concealed it in the text without mentioning it in the subtitle to his Principles.

Our two thinkers do not differ much in their pessimistic anthropology of man, but their attitudes towards the two main normative ethical notions of the time, vice and virtue, do not have much in common: Berkeley provides a new explanation and role for them by his innovative metaphysics and the idea that God speaks to us directly, telling us how to behave, thus strengthening these two traditional concepts and working within the prevailing Christian paradigm, while Mandeville attempts a deconstruction of them, revealing them as a sociological fiction and explaining their emergence in a naturalistic and evolutionary ${ }^{16}$ framework. But still the question remains: how is such a radical divergence concerning these two frequented words even possible? The problem of the traditional moralist words and their ingrained positive and negative connotations, together with their normative function, will be further analysed in the next chapter.

\footnotetext{
${ }^{14}$ See (Alc II, 105), where to Lysicles exclaiming "How many hard words and intricate, absurd notions had possessed the minds of men before our philosophers appeared in the world!" Crito calmly retorts: "I had rather my wife and children all believed what they had no notion of, and daily pronounced words without a meaning, than that any one of them should cut his throat, or leap out of a window." emphasizing the pragmatic and emotive function of some words.

${ }^{15}$ In the poem The Grumbling Hive, which forms the nucleus of the Fable, all the economic activity seems to be of the criminal type: 'Sharpers, Parasites, Pimps, Players, Pick-pockets, Coiners, Quacks, Southsayers ... These were call'd Knaves, but bar the Name, The grave Industrious were the same: All Trades and Places knew some Cheat, No Calling was without Deceit" (Fable, 19-20).

${ }^{16}$ For a cogent reading of Mandeville as an evolutionist, see Hundert $(1994,49-63)$, as well as his influence on Darwin in Hundert (1994, 242 - 243).
} 


\section{The Case Study of "Luxury"}

To account for this semantic dissonance between our two thinkers, we descend from the level of vice/virtue to the level of one particular vice, namely "luxury". Now, luxury ${ }^{17}$ is one of few terms that have changed their polarity over time: it started as a negative term and is now largely positive, hence it can appear in advertisement, for example. Mandeville and Berkeley were writing their books during the time of this momentous transformation.

In Plato's Republic II we find a description of a society where the human needs for food, clothing and dwelling are served by strictly functional items, the dishes are vegetarian, clothing worn only in winter and the houses are without decoration. Glaucon is not happy with this "city of pigs" and wants some furniture and civilized food. Socrates explains that if the wish for more luxurious items is granted, the society becomes fevered and inflamed, and it will have to wage war to obtain these luxuries which go beyond necessity. Moreover, upon acquiring these luxuries, the warriors wallow in them and become soft and weak, being in turn defeated by other, less softened warriors. In the Roman context, virtue is the property of man, vir, and luxuria works the other way, to weaken the warrior and make him woman-like, it is thus the archetypal vice. In the Greco-Roman histories, luxury enters a healthy city from the East and weakens it so that it is easily defeated. The Romans enact laws to fight it and limit spending on banquets and clothes. The sumptuary laws testify to luxury becoming one of the central and normative concepts of the culture. Christian Europe takes over the pagan concepts of vice and virtue and reads it retroactively into the Bible, identifying vices with sins. Luxury became a sin in opposition to sobriety and chastity. Medieval sumptuary laws were enacted prescribing dress and food to subjects, in England the last passing in 1604.

Berkeley uses the classical concept of luxury with all of its connotations. On the theoretical level, he accepts the explanatory common-place of Roman historians that luxury is the cause of the downfall of societies: "Sallust observes, that a little before the downfall of the Roman greatness, avarice (the effect of luxury) had erased the good old principles of probity and justice... consult any historian, look into any writer. See, for instance, what Xenophon and Livy say of Sparta and Rome...” (Alc II, 75-76, my italics). He proves a faithful reader of Plato: "luxury ... makes a nation, like a diseased, pampered body, look full and fat with one foot in the grave" (Alc II, 105, my italics) when he claims that luxury is the main programme of the free-thinkers' campaign. On the practical level he gives his wife a spinning wheel as a wedding gift and encourages her to wear home spun clothes, refusing to buy imported fashionable cloths. ${ }^{18}$ On the political level, when making his proposal to set up an Irish national bank in Dublin, Berkeley suggests to raise

\footnotetext{
${ }^{17}$ The following history of the concept of luxury follows that provided by (Berry 1994)

18 (Hight 2013, 260): “... there shall never be one yard of silk bought for the use of myself, herself, or any of our family." Mrs Berkeley seems to have been happy with this arrangement.
} 
the original capital by taxing imported wine and "foreign silks, linens, and laces" (Hight 2013, 399). And he even lobbies for re-introducing sumptuary laws, writing in 1742 to John Percival, MP for Westminster: "As luxury seems the real original root of those evils under which we groan ... must it not seem at the same time that ... sumptuary laws are highly expedient if we would cut out the core of the national evil. To attempt or even mention such things now would be madness ..." (Hight 2013, 448). He called such plans "utopian schemes" and admitted taking Plato's Republic "if not for a rule, yet for an incentive", knowing well there was much political opposition to the old concept of luxury with its legal ramifications.

Indeed, the fact that his wife wore home spun was held against him during the crucial deliberations in 1729 , when it was finally decided that the government grant to fund his Bermuda college would not be paid. ${ }^{19}$

On the other side, there was a new meaning of the word "luxury" being advocated by proponents of trade, shorn of its negative connotations. Nicholas Barbon in his Discourse of Trade (1690) argued that too much frugality hurts trade, and that prodigality is "a Vice that is prejudicial to the Man but not to Trade" (Berry 1994, 111), a contrast that will form the basis of Mandeville's position. A new modern anthropology of Hobbesian mould provides the support here, a view of man and his infinite desires, which can never be satisfied and thus cannot be excessive, i.e. luxurious in the traditional sense. Barbon commends expenditure on buildings and clothes as promoting trade, fashion is seen as beneficial, for man is naturally ambitious and wants to outdo others in the way he looks. The Enlightenment thinkers eventually divide into two camps, the traditional moralists condemning luxury and fashion, including Locke, Shaftesbury, Berkeley, Rousseau and Lord Kames, and the progressive, permissive wing with Mandeville, Voltaire, Hume and Smith. Berry fittingly calls their divorcing questions of commerce and politics from those of morality "de-moralization of luxury" (Berry 1994, 138). The word "luxury" itself is torn between them, being ambivalent in the eighteenth century and the subject of a fierce culture war.

Mandeville's take on the debate is original. There is nothing in his position that is not already at least implicitly in Barbon, but whereas Barbon expresses his commendation of luxury in straight, objective terms, Mandeville pretends to still condemn it. He uses the moralist's negative words to force them into semantic paradoxes. He defines luxury strictly as "that (which) is not immediately necessary to make Man subsist as he is a living Creature" (Fable, 107). The justification for the definition's strictness is that what is luxury for one person may not be luxury for a person of a higher rank and that therefore a looser

${ }^{19}$ His friend Benson wrote Berkeley from London: “... the good example they hear your Lady is setting of beginning a manufacture which herself will wear, they look upon as a dangerous precedent, and what may prove in time prejudicial to the manufactures of England" (Hight 2013, 281). 
definition would make the word so vague as to be useless. This little definitional trick enables Mandeville to stretch the meaning of luxury to cover everything, at the expense of emptying it of any sensible descriptive content. Berry puts the point succinctly: "It enables him to claim (strictly) that everything is a 'luxury' but, of course, this is also to say equally that nothing is a luxury" (Berry 1994, 129). Now that the concept of "luxury" is untied from its surrounding concepts he can play with it as he wishes, he can claim that luxury is bad but it is so pervasive that if you want to have a "decent" standard of living, you have to embrace it, and he fills hundreds of pages to that effect.

One consequence of Mandeville's definitional approach, and also a point Berkeley will attack, is the destruction of the concept of "moderation". Now these two concepts are defined against each other and hold each other in their respective positions, if you enlarge "luxury" to include everything, then you empty the concept of "moderation". Mandeville recognises the intimate connection between these two concepts and the danger it poses to his definition of luxury: "If you tell me, that Men may make use of all these Things with Moderation, and consequently that the Desire after them is no Vice, then I answer, that either no Degree of Luxury ought to be call'd a Vice, or, that it is impossible to give a Definition of Luxury..." (Letter, 58, my italics). He is at his most passionate and bellicose when describing moderation: "Oh rare Doctrine! Oh easy Christianity! To be moderate in numberless Extravagancies ... But if we grant the Possibility of it, how shall we know and be convinced that they are sincere ... when we have Nothing but their bare Word for it ...?" (Letter, 41, my italics) So he dispatches moderation by claiming it is hypocrisy.

Berkeley, on the other hand, finds room for moderation, and blocks this pre-emptive move: "Lys. ... what moves men to build and plant but vanity, and what is vanity but vice? Euph. But if a man should do those things for his convenience or pleasure, and in proportion to his fortune, without a foolish ostentation or over-rating them beyond their due value, they would not then be the effect of vice; and how do you know but this may be the case?" (Alc II, 73, my italics) By allowing at least the possibility of sincerity, Berkeley attempts to save moderation and consequently, luxury. Mandeville is keen to deny even this possibility, rejecting all external and objective criteria such as ostentation, and limiting himself to the verbal assurance of moderation. But by doing this he does to hypocrisy what he did to luxury, stretch it so much that he squeezes all meaning out of it.

When it comes to the struggle for the word luxury, Berkeley seems to be on stronger ground for he defends the way it is used, while Mandeville has to twist it and other words, too, to get the result he wants. But such as analysis would underestimate the acuteness of Mandeville's ear, for he hears changes to it that Berkeley is unwilling to countenance. "Luxury" often collocated with verbs "enervate" and "effeminate", both were negative descriptions of its negative influence. Mandeville mentions both and of the first one he says: "the great Dread I had more particularly against the Word, to enervate, and some 
consequent Thoughts on the Etymology of it, did me Abundance of Good when I was a Schoolboy: But since I have seen something of the World, the Consequences of Luxury to a Nation seem not so dreadful to me as they did" (Fable, 118). He probably describes a general decline in the efficacy of these words, for "luxury" was a contested word at the time. But to claim that the changes were driven or effected by Mandeville or any other writer, as Bentham did, would be too optimistic. Such a momentous change as the reverse in the polarity of a word is rarely caused by one speaker of the language, or even a group of speakers. The fact that no sumptuary laws had been passed for more than a century before our two writers, not even during the fundamentalist Commonwealth era, may have something to do with these broad changes, of which their writings form merely a record.

To sum up, we have identified two points of contact between our writers, which went beyond their misrepresentations of each other: the question of the status of Mandeville's doctrine and its potential political consequences, and the role of moderation and consequently of hypocrisy in it. And what about the dispute itself between Mandeville and Berkeley? In the short term, Berkeley, together with other divines, was successful in preventing the freethinkers from subverting the morals, religion and political establishment of the United Kingdom. The happy marriage of the new science and old piety saw off the deist threat, ${ }^{20}$ with Berkeley's optical metaphor of God speaking directly to His creatures being of particular importance. In the long term, Mandeville's opinions prevailed, with the word "luxury" losing the remnants of its normative function and opprobrium as well as becoming a positive term. But its ambivalence prevented both thinkers from engaging in a meaningful discussion, for they were pulling it in opposite directions.

\section{Bibliography}

BERKELEY, G. (1738): A Discourse Addressed to Magistrates and Men in Authority. London: J. Roberts.

BERMAN, D. (1988): A History of Atheism in Britain: From Hobbes to Russell. New York: Croom Helm.

BERRY, CH. J. (1994): The Idea of Luxury A Conceptual and Historical Investigation. Cambridge: Cambridge University Press.

CLARK, J. C. D. (2000): English Society, 1660 - 1832: Religion, Ideology and Politics during the Ancien Régime. Cambridge: Cambridge University Press.

HIGHT, M. A. (2013): The Correspondence of George Berkeley. Cambridge: Cambridge University Press.

HUNDERT, E. J. (1994): The Enlightenment's Fable. Cambridge: Cambridge University Press.

${ }^{20}$ (Clark 2000, 360): "The main reasons for the failure of the Freethinkers must be sought within the Church. Although the Deist campaign has rightly drawn the attention of historians, the response of orthodox churchmen was more widespread, more scholarly, and polemically more effective." 
KAYE, F. B. (1924): Introduction. In: Kaye, F. B. (ed.): The Fable of the Bees. Oxford: Oxford University Press.

LUCE, A. A. - JESSOP, T. E. (1967): The Works of George Berkeley, Bishop of Cloyne, Volume Three: Alciphron, or the Minute Philosopher. London: Thomas Nelson and Sons Ltd.

OLSCAMP, P. J. (1970): The Moral Philosophy of George Berkeley. The Hague: Martinus Nijhoff. TOLONEN, M.: Dialogue between Mandeville and Berkeley. Forthcoming.

VINER, J.: Introduction. In: Viner, J. (ed.): A Letter to Dion. Wroclaw: Amazon Fulfilment.

WALMSLEY, P. (1990): The Rhetoric of Berkeley's Philosophy. Cambridge: Cambridge university Press.

This paper is a result of Grant No. 17-06904S On the Limits of Reason in the Age of Reason: Disputes in the $18^{\text {th }}$ Century Philosophy realized at the University of Hradec Králové.

Marek Tomeček

University of Hradec Králové

Philosophical Faculty

Department of Philosophy and Social Sciences

Náměstí Svobody 331

50002 Hradec Králové

Czech Republic

e-mail: marektomecek@yahoo.co.uk

ORCID ID: https://orcid.org/0000-0001-9046-3567 